\title{
Księgozbiory beletrystyczne w polskich akademickich bibliotekach specjalistycznych
}

Streszczenie. Gromadzenie i udostępnianie literatury beletrystycznej w bibliotekach uniwersyteckich jest sprawą oczywista, bowiem tego typu literatura jest warsztatem pracy określonej grupy naukowców i studentów uniwersytetów.

Statutowego obowiązku gromadzenia beletrystyki nie mają natomiast specjalistyczne biblioteki techniczne, medyczne, rolnicze, ekonomiczne, wojskowe, niemniej w niektórych z nich jest ona dostępna.

W artykule omówione zostaną: proweniencja księgozbiorów beletrystycznych w akademickich bibliotekach specjalistycznych, zainteresowanie beletrystyką ze strony użytkowników, sposoby udostępniania i pozyskiwania nowości, źródła finansowania.

Słowa kluczowe: polskie akademickie biblioteki specjalistyczne, księgozbiory beletrystyczne.

\section{Wprowadzenie}

We wszystkich bibliotekach akademickich zbiory gromadzone są zgodnie z potrzebami procesu badawczego i dydaktycznego. Z obowiązków statutowych bibliotek uniwersyteckich wynika konieczność gromadzenia m.in. literatury pięknej, szczególnie z myślą o studentach i pracownikach naukowych studiów filologicznych, co zapewnia im odpowiedni warsztat pracy i dostęp do lektur.

W profilu specjalistycznych bibliotek technicznych, medycznych, rolniczych, ekonomicznych, wojskowych literatura beletrystyczna się nie mieści. Czy jednak nie ma w tych bibliotekach miejsca na kryminały, tomiki wierszy czy lektury szkolne? 
W referacie na II Seminarium: Gromadzenie zbiorów - sztuka wyboru Małgorzata Kuziela pisze, że będąca w strukturze Biblioteki Głównej Politechniki Wrocławskiej Biblioteka Beletrystyczna „wydaje się ewenementem pośród wyższych uczelni technicznych" ${ }^{\prime 1}$. Czy faktycznie jest to odosobniony przypadek?

Inspiracją do przeprowadzenia analizy polskich akademickich bibliotek specjalistycznych pod tym kątem było przeniesienie w 2015 roku zbiorów Biblioteki Pracowniczej Akademii Górniczo-Hutniczej do Biblioteki Głównej (BG).

\section{Księgozbiór beletrystyczny w AGH}

Historia księgozbioru beletrystycznego w Akademii Górniczo-Hutniczej im. Stanisława Staszica w Krakowie (AGH) sięga drugiej połowy lat 50., kiedy to działający na terenie uczelni Związek Nauczycielstwa Polskiego (ZNP) zainicjował powstanie biblioteki dla pracowników. Na kolekcję składały się lektury szkolne, literatura sensacyjna, piękna, podróżnicza, przewodniki, poradniki. Początkowo Biblioteka Związkowa utrzymywana była ze środków ZNP. Później wydatki związane z utrzymaniem biblioteki, tj. koszty lokalu, zakupu nowości, zatrudnienia jednego etatu zobowiązały się pokrywać władze rektorskie z budżetu uczelni i Zakładowego Funduszu Świadczeń Socjalnych.

Biblioteka cieszyła się dużym zainteresowaniem ze strony zarówno czynnych pracowników, jak i emerytów i rencistów, choć niedogodnością były ograniczenia w dostępie do biblioteki i do informacji o jej zasobach, co wynikało przede wszystkim z jednoosobowej obsługi bibliotekarskiej czy braku zastosowania nowoczesnych rozwiązań (np. brak katalogu komputerowego).

Wiele zastrzeżeń budziły też warunki lokalowe. Książki na regałach układane były w dwóch, a czasem nawet w trzech rzędach. Przy braku de facto katalogu mało kto wiedział, co znajduje się na półkach, szczególnie w drugim czy trzecim rzędzie.

Biblioteka zlokalizowana była w atrakcyjnym, z punktu widzenia administracji centralnej, miejscu. Wielokrotnie podejmowano próby przeniesienia jej gdzie indziej, lecz wszystkie one kończyły się niepowodzeniem.

1 M. Kuziela, Dary kontrolowane - jak wptywać na jakość i ilość darów wprowadzanych do księgozbioru, w: Gromadzenie zbiorów - sztuka wyboru, Materiały konferencyjne 11, II Seminarium, Wrocław, 23-24 czerwca 2005 r., Wrocław 2005, http://www.ebib.pl/ publikacje/matkonf/grom2/kuziela.php [dostęp: 2.06.2016]. 
Między innymi w projekcie rozbudowy BG z 2002 roku przewidywano wydzielenie miejsca dla tej jednostki. Niestety, z powodu braku środków finansowych ówczesna inwestycja nie doszła do skutku, a Biblioteka Związkowa nie uzyskała nowego pomieszczenia. W 2002 roku zarządzeniem rektora biblioteka przekształcona została w Bibliotekę Pracowniczą (BP), a nadzór merytoryczny nad nią powierzono Działowi Socjalno-Bytowemu.

Po kilkunastu latach do sprawy BP powrócono ponownie. Z początkiem 2015 roku rektor AGH zwrócił się do dyrekcji BG o rozważenie możliwości wygospodarowania miejsca dla zbiorów BP w nowo wyremontowanym i rozbudowanym ${ }^{2}$ gmachu BG. Należy wyjaśnić, że w wyniku inwestycji powierzchnia BG wzrosła jedynie o ok. $1000 \mathrm{~m}^{2}$, a więc o wiele mniej, niż to przewidywał wcześniejszy projekt.

$W$ ramach modernizacji wprowadzono zmiany organizacyjne i lokalowe, tak by BG stanowiła jeden dobrze działający organizm, gdzie zachowana jest płynność procesów bibliotecznych. Nie było możliwe wskazanie w BG, już po wykonaniu projektu i zakończeniu inwestycji, pomieszczenia dla BP jako wydzielonej organizacyjnie i lokalowo jednostki. Jedynym realnym rozwiązaniem było włączenie księgozbioru do zbiorów BG z zachowaniem odrębności kolekcji.

Władze uczelni zaakceptowały ten kierunek działań, toteż wkrótce w BG powołany został zespół roboczy do opracowania koncepcji przeniesienia BP do BG oraz szczegółowego harmonogramu prac. Zaproponowane rozwiązanie zakładało przeniesienie ok. 12 tys. książek beletrystycznych do Strefy Wolnego Dostępu (SWD). Zgodnie z projektem SWD miała pomieścić ok. 70 tys. podręczników akademickich. Ze strefy postanowiono wydzielić część przestrzeni wraz z regałami dla beletrystyki. Oznaczało to całkowitą reorganizację SWD, przesunięcie dotychczasowych działów księgozbioru dydaktycznego, ścieśnienie lub usunięcie części podręczników. By tego dokonać, należało, na podstawie danych z systemu komputerowego, przeprowadzić analizę wykorzystania księgozbioru dydaktycznego BG, a ponadto przejrzeć wszystkie podręczniki pod kątem ich stanu fizycznego, w rezultacie czego książki rzadziej wykorzystywane i podniszczone zostały wycofane do magazynu bądź zubytkowane.

Ostatecznie, po zawarciu uzgodnionego z dyrektorem BG porozumienia pomiędzy prorektorem ds. ogólnych a przedstawicielami dwóch działających na uczelni związków zawodowych (ZNP i NSZZ „Solidarność"), przeprowadzono inwentaryzację, a następnie księgozbiór BP został prze-

\footnotetext{
2 Inwestycja realizowana była w latach 2010-2014.
} 
niesiony do BG, opracowany w systemie komputerowym, ustawiony na wydzielonych regałach SWD i udostępniony czytelnikom. Cały proces trwał kilka miesięcy, choć początkowo zakładano, że samo opracowanie książek zajmie około roku. Jednak dzięki ogromnym już dziś zasobom Narodowego Katalogu Centralnego NUKAT wiele opisów można było przekopiować do katalogu lokalnego, co znacznie przyspieszyło opracowanie.

Największym problemem, z jakim przyszło się zmierzyć, był problem mentalny. Wielu dotychczasowych czytelników bardzo obawiało się czekających ich zmian, kierowali więc do władz uczelni pisma, petycje, apele o odstąpienie od podjętej decyzji o przeniesieniu księgozbioru do BG. Dzisiaj emocje opadły i powoli czytelnicy oswajają się z nowym, komfortowym, jasnym pomieszczeniem, miłą i kompetentną całodzienną obsługa, nowymi dla tej biblioteki technologiami (katalog komputerowy, system RFID, możliwość samodzielnych wypożyczeń itp.). W czerwcu 2016 roku oferta książek została poszerzona o e-booki. Za zgodą władz rektorskich z e-booków korzystać mogą także studenci. Przez kolejne miesiące prowadzony będzie monitoring pod kątem zainteresowania tą kolekcją i w zależności od jego wyników podjęte zostaną decyzje o utrzymaniu, poszerzeniu lub rezygnacji z kolekcji e-booków.

\section{Księgozbiory beletrystyczne w innych akademickich bibliotekach specjalistycznych}

W celu zdiagnozowania, czy podobnie jak w BG PWr i BG AGH także $\mathrm{w}$ innych akademickich bibliotekach specjalistycznych funkcjonują kolekcje beletrystyczne, zwrócono się, za pośrednictwem listy Konferencji Dyrektorów Bibliotek Akademickich Szkół Polskich, do dyrektorów ww. bibliotek z prośbą o informację, czy ten rodzaj literatury w kierowanych przez nich bibliotekach występuje.

Z uzyskanych odpowiedzi wynika, że w kilku bibliotekach wcześniej istniały księgozbiory beletrystyczne, ale $\mathrm{w}$ większości zostały zlikwidowane. Powodem był brak miejsca, brak środków na zakup nowości czy opłacenie etatu do obsługi kolekcji. Księgozbiory zostały przekazane do bibliotek szkolnych, bibliotek na Litwie, domów dziecka czy do ośrodków wczasowych danej uczelni ${ }^{3}$. Część zbiorów, która w bibliotekach pozostała, jest udostępniana w formie bookcrossingu (bez opracowania, bez obsługi, bez zakupu nowości, jednym słowem - nieomal bezkosztowo).

3 Biblioteki Szkoły Głównej Handlowej, Politechniki Warszawskiej, Politechniki Gdańskiej, Politechniki Krakowskiej. 
Z drugiej strony w niektórych bibliotekach akademickich pojawiły się plany utworzenia kolekcji beletrystycznych. Przykładem jest Biblioteka Główna Politechniki Lubelskiej, która niedawno podobną inicjatywę podjęła, czy Biblioteka Główna Politechniki Białostockiej, która nosi się z takim zamiarem.

Ciekawe rozwiązanie zastosowano w Bibliotece Uczelni Łazarskiego polegające na udostępnianiu deponowanych w tejże uczelni ruchomych kompletów księgozbioru Biblioteki Publicznej w dzielnicy Warszawa-Mokotów. Tak więc Biblioteka Uczelni Łazarskiego nie kupuje i nie opracowuje książek beletrystycznych, ale je wypożycza, pełniąc tym samym swego rodzaju funkcję punktu bibliotecznego. Wprawdzie z informacji uzyskanej od dyrektora Biblioteki Uczelni Łazarskiego wynika, że „książki, mimo wolnego dostępu, chodzą słabo (wcześniej bookcrossing w ogóle nie wypalił), ale są do dyspozycji" ${ }^{4}$, niemniej uczelnia w ten sposób próbuje realizować zadania wychowawcze.

W wyniku analizy odpowiedzi dyrektorów bibliotek akademickich uzyskano informację o tym, że własne kolekcje beletrystyczne istnieją w czternastu akademickich bibliotekach specjalistycznych (zob. Wykaz 1).

\section{Wykaz 1. Akademickie biblioteki specjalistyczne, które posiadają zbio- ry beletrystyczne}

\section{Uczelnie techniczne, w tym wojskowe i morskie:}

1. Akademia Górniczo-Hutnicza im. Stanisława Staszica w Krakowie (AGH)

2. Akademia Marynarki Wojennej im. Bohaterów Westerplatte, Gdynia (AMW)

3. Akademia Morska w Szczecinie (AM)

4. Politechnika Lubelska (PL)

5. Politechnika Łódzka (PŁ)

6. Politechnika Opolska (PO)

7. Politechnika Śląska (PŚl)

8. Politechnika Wrocławska (PWr)

9. Wojskowa Akademia Techniczna im. Jarosława Dąbrowskiego w Warszawie (WAT)

\section{Uczelnie rolnicze/przyrodnicze:}

10. Szkoła Główna Gospodarstwa Wiejskiego w Warszawie (SGGW)

11. Uniwersytet Przyrodniczy we Wrocławiu (UP Wr)

4 Z pisemnej wypowiedzi dyrektora Biblioteki Uczelni Łazarskiego (dokumentacja autorki). 


\section{Uczelnie medyczne:}

12. Pomorski Uniwersytet Medyczny w Szczecinie (PUM)

13. Gdański Uniwersytet Medyczny (GUM)

Inne:

14. Wyższa Szkoła Biznesu - NLU w Nowym Sączu (WSB-NLU).

Badane zjawisko okazało się nieodosobnione, dlatego zdecydowano się na przeprowadzenie dalszych analiz. Dyrektorów bibliotek gromadzących beletrystykę poproszono o udzielenie odpowiedzi na kilka pytań i skomentowanie wskazanych zagadnień:

1. Krótka charakterystyka księgozbioru.

2. Proweniencja księgozbioru (budowany od początku w bibliotece centralnej/głównej uczelni, przekazany z innej jednostki, księgozbiór obcy pozostający w depozycie, inne).

3. Sposób pozyskiwania pozycji do zbiorów (zakup? dar?).

4. Jeśli zakup, to jakie źródło finansowania?

5. Czy jest to biblioteka wydzielona w strukturze biblioteki (głównej/ centralnej uczelni)?

6. Obsługa biblioteki, kolekcji (jeśli jest wydzielona)?

7. Czy jest to wydzielona kolekcja?

8. Jeśli tak, to czy jest rejestrowana w oddzielnym inwentarzu?

9. Kto opracowuje zbiory (np. wydzielone stanowisko/osoba ds. oprac. beletrystyki, oprac. w oddziale opracowania zbiorów, inne rozwiązania, jakie)?

10. Informacja o zbiorach (w katalogu komputerowym biblioteki centralnej/głównej uczelni, w tym samym oprogramowaniu, ale jako odrębna baza, odrębna kolekcja, inne).

11. Na jakiej podstawie dokonuje się zakupów?

12. Czy jest $\mathrm{w}$ wolnym dostępie?

13. Wielkość księgozbioru (liczba tytułów, liczba egzemplarzy).

14. Użytkownicy (wszyscy zapisani, pracownicy/emeryci własnej uczelni, pracownicy i studenci własnej uczelni, inne - jakie).

15. Roczna liczba wypożyczeń.

16. Dostępność do księgozbioru (dni, godziny).

Ostatecznie wyniki opracowano na podstawie zarówno odpowiedzi pisemnych, jak i przeprowadzonych wywiadów telefonicznych.

$\mathrm{Z}$ przedstawionej charakterystyki księgozbiorów beletrystycznych wynika, że we wszystkich czternastu bibliotekach jest to literatura zarówno polsko-, jak i obcojęzyczna. Księgozbiory obejmują literaturę piękna, sensacyjną, biograficzna, popularnonaukową fantastykę, poezję, książki o tematyce historycznej. Niektóre z kolekcji posiadają w swoim obrębie 
dodatkowe, specyficzne działy jak np. AM w Szczecinie - marynistykę, PUM w Szczecinie - beletrystykę tematycznie związaną z medycyną czy AMW w Gdyni - „żółte tygrysy”.

Różna jest proweniencja księgozbiorów. W ośmiu bibliotekach księgozbiory beletrystyczne od samego początku stanowiły część księgozbioru centralnej (głównej) biblioteki danej uczelni (PO, PL, WAT, UP Wr, PUM, WSB-NLU). W pozostałych przypadkach trafiły do bibliotek głównych w formie darów jako całe kolekcje bądź jako pojedyncze tytuły przekazywane bibliotece indywidualnie przez czytelników (GUM). Najczęściej kolekcje te powstawały w latach 50 . XX wieku jako biblioteki pracownicze zakładane przez ZNP (AGH, SGGW, PŁ). Nieco inna była sytuacja na Politechnice Śląskiej, gdzie księgozbiór beletrystyczny zapoczątkowany został z inicjatywy dyrektora Biblioteki Głównej, niezależnie od istniejącej biblioteki ZNP. Gdy na uczelni rozpoczęto remont pomieszczeń biblioteki ZNP, książki przeniesiono do Biblioteki Głównej. Miało to być rozwiązanie tymczasowe, ale ostatecznie biblioteka beletrystyczna ZNP połączona została z kolekcją beletrystyczną BG PŚl i w tej formie z powodzeniem funkcjonuje już od kilku lat.

Początek kolekcji beletrystycznej na Politechnice Wrocławskiej dała Biblioteka Klubu Studentów PWr. Po kilku miesiącach zbiory włączono do Biblioteki Głównej Politechniki.

Księgozbiór beletrystyczny AWM z kolei wywodzi się z Biblioteki Oświatowej Uczelni. Po scaleniu księgozbioru z Biblioteką Naukową jednostce nadano nową nazwę: Biblioteka Główna Akademii Marynarki Wojennej.

Natomiast trzon kolekcji beletrystycznej AM stanowią książki z bibliotek na statkach, przekazane Bibliotece Głównej przez Polską Żeglugę Morską. Część książek pochodzi z biblioteki, która wcześniej mieściła się w akademiku.

W większości omawianych bibliotek książki pozyskiwane są zarówno w ramach zakupów, jak i darów. Środki na zakup przewidziane są w budżetach bibliotek lub pochodzą z funduszu socjalnego (PŚl, AGH). Zasoby Biblioteki GUM zasilane są wyłącznie dzięki darom. W wielu przypadkach, m.in. na Politechnice Wrocławskiej, sami czytelnicy „chętnie uczestniczą $\mathrm{w}$ tworzeniu księgozbiorów, obdarowując bibliotekę interesującą literaturą"5.

Zakupy beletrystyki dokonywane są na podstawie dezyderatów zgłaszanych przez czytelników, zapowiedzi wydawniczych oraz rozpoznania rynku przez pracowników centralnej biblioteki uczelni. W PŚl i AGH

\footnotetext{
5 M. Kuziela, op.cit.
} 
planowane do zakupu wykazy książek dodatkowo uzgadniane są ze związkami zawodowymi (ZNP i NSZZ "Solidarność").

W czterech przypadkach biblioteka beletrystyczna jest wydzielona w strukturze biblioteki głównej (PWr, SGGW, PŁ, WAT); w dalszych ośmiu stanowi oddzielną kolekcję (AM, AMW, PL, UP Wr, PUM, GUM, PŚl, AGH). W PO i WSB-NLU nie ma ani wyodrębnienia w strukturze, ani wydzielenia kolekcji, niemniej przy wyszukiwaniu $\mathrm{w}$ katalogu jest możliwość wysortowania książek beletrystycznych (PO).

Omawiane kolekcje z reguły obsługiwane są przez pracowników biblioteki głównej, oddziału udostępniania, wypożyczalni. Przykładowo w AGH, mimo że wraz ze zbiorami przejęty został pracownik (ze średnim wykształceniem) dotychczas prowadzący bibliotekę pracownicza, to obecnie zakup, opracowanie i udostępnianie zbiorów beletrystycznych spoczywają na pracownikach kilku oddziałów BG, od Oddziału Gromadzenia i Uzupełniania Zbiorów, poprzez Oddział Opracowania i Oddział Magazynów, po Oddział Udostępniania Zbiorów. Zniknął też problem braku dostępu do biblioteki spowodowanego urlopem czy chorobą jej pracownika.

Kolejne pytanie dotyczyło inwentarza. W jedenastu bibliotekach kolekcja beletrystyczna rejestrowana jest $\mathrm{w}$ oddzielnym inwentarzu (AGH, PŁ, PWr, PŚl, AMW, AM, WAT, SGGW, UP Wr, PUM, GUM), w trzech (PL, PO, WSB-NLU) - w ciągu inwentarza biblioteki głównej. We wszystkich czternastu przypadkach zbiory opracowywane są przez pracowników biblioteki głównej.

Katalogowanie zbiorów odbywa się w posiadanym przez daną bibliotekę systemie komputerowym, z tym że w kilku przypadkach jest to oddzielna baza (np. PŁ, UP Wr, PWr), w pozostałych opisy przechowywane są w tej samej bazie co opisy literatury naukowej. Biblioteka GUM zastosowała filtr "GUMed Beletrystyka” ułatwiający przeszukiwanie tego podzbioru. W AGH utworzono fasety umożliwiające zawężenie wyszukania do gatunku/formy (np. powieści, nowele, przewodniki) lub do lokalizacji (Biblioteka Pracownicza, BP - Magazyn, BP - Strefa Wolnego Dostępu). Biblioteka PL planuje utworzenie odrębnej fasety, gdy w zbiorze znajdzie się więcej pozycji beletrystycznych.

Aż $\mathrm{w}$ dziewięciu przypadkach księgozbiór beletrystyczny w całości udostępniany jest na zasadzie wolnego dostępu; w AGH poza SWD znajduje się tylko niewielka część zbiorów rzadziej wypożyczanych. Jedynie do części kolekcji swobodny dostęp ma czytelnik w UP Wr. W GUM, PO i AM cały zbiór umieszczony jest w magazynie.

Jak wspomniano wcześniej, w części omawianych przykładów księgozbiory wywodzą się z bibliotek związkowych, wobec czego uprawnienia 


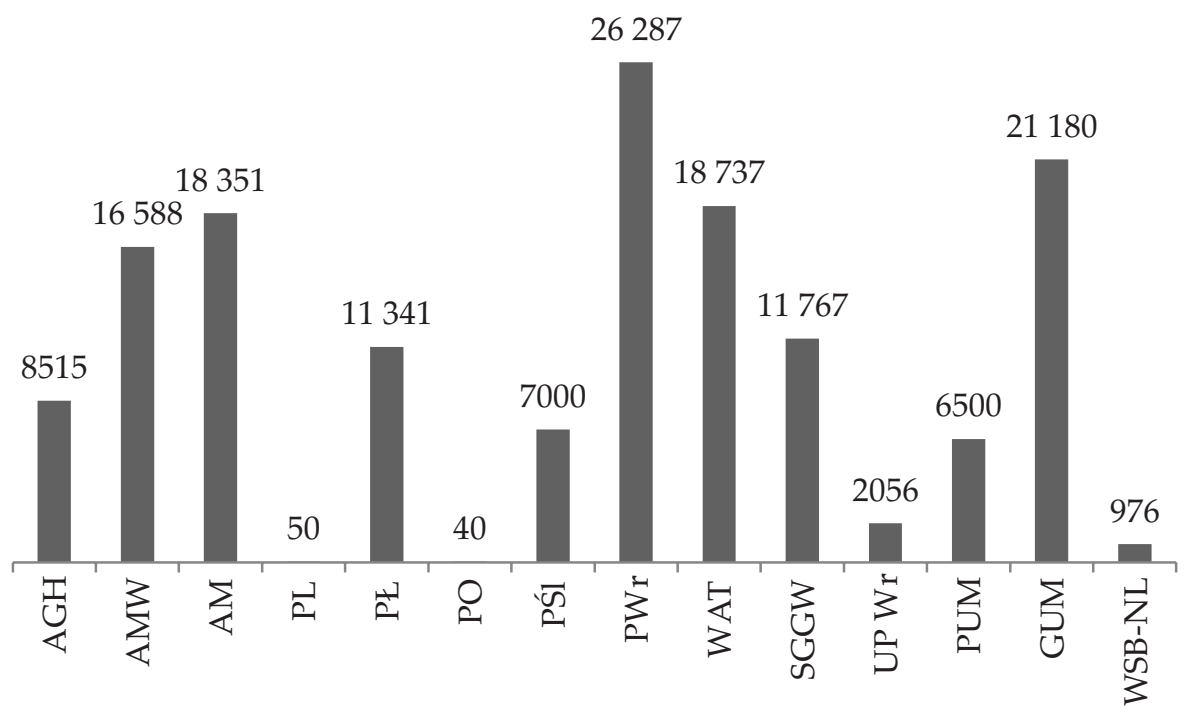

Wykres 1. Wielkość księgozbioru beletrystycznego (stan na grudzień 2015 roku)

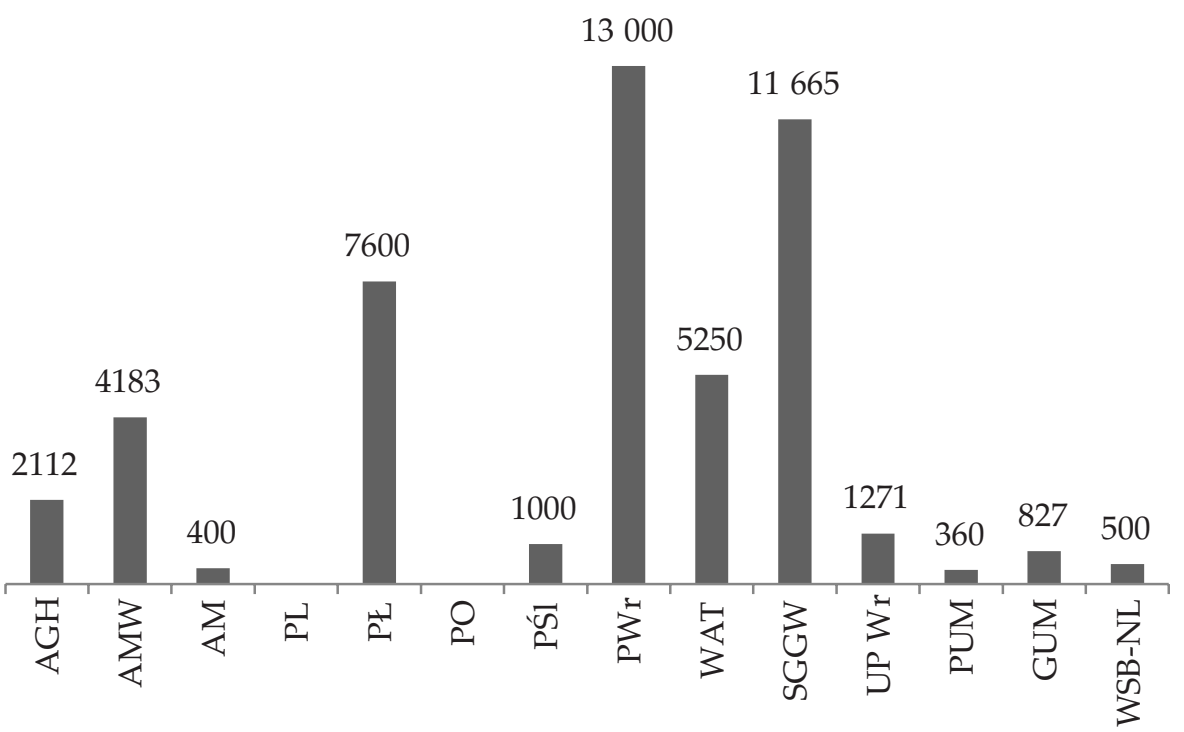

Wykres. 2. Roczna liczba wypożyczeń beletrystyki (dane za rok 2015)

do wypożyczania, na wniosek tychże organizacji związkowych, nadal posiadają tylko pracownicy, emerytowani pracownicy i renciści uczelni (AGH, PŁ). Być może w AGH, w wyniku zabiegów dyrekcji BG, sytuacja ta zmieni się $\mathrm{w}$ niedalekiej przyszłości. W części badanych bibliotek książki wypożycza się wszystkim grupom zarejestrowanych użytkowników 


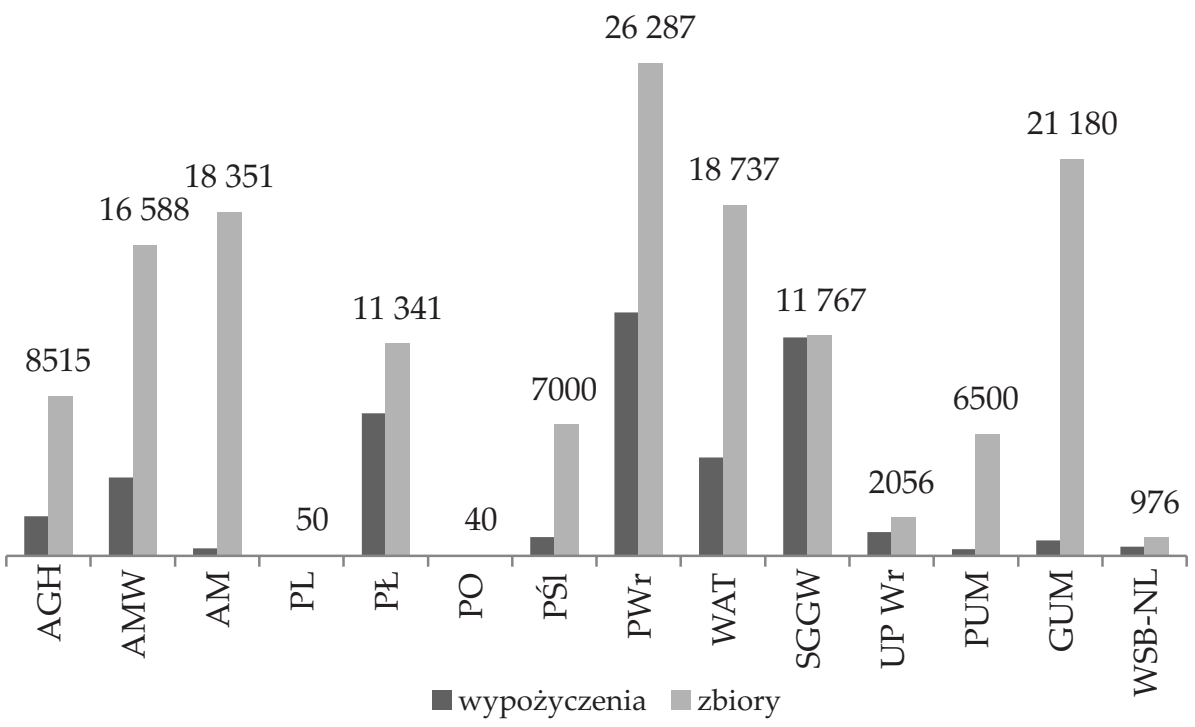

Wykres. 3. Porównanie liczby wypożyczeń z wielkością zbiorów

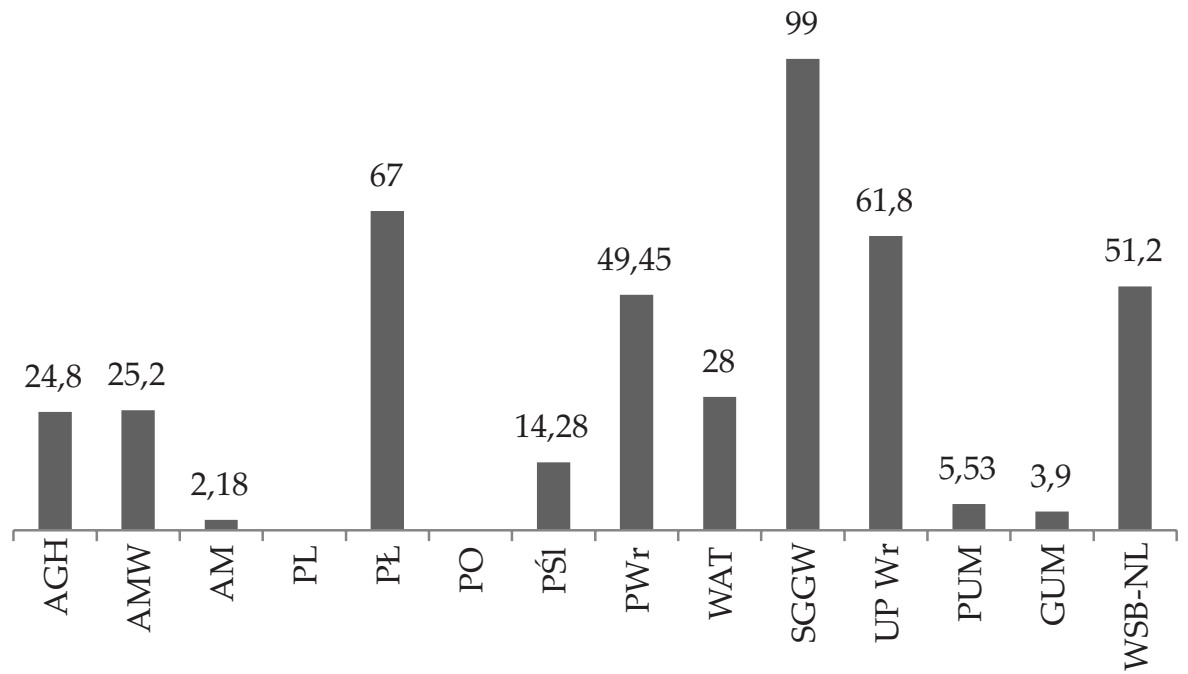

Wykres. 4. Procentowe wykorzystanie zbiorów beletrystycznych

(PL, PO, PŚl, AMW, AM, WAT, PUM, GUM), choć w niektórych przypadkach użytkownikom zewnętrznym - po wpłaceniu kaucji.

Wielkość omawianych kolekcji jest bardzo różna i wynosi od ok. 40 pozycji (niedawno powstała biblioteka PO) do ponad 26 tys. (PWr).

W większości bibliotek księgozbiory beletrystyczne dostępne są w godzinach pracy biblioteki lub wypożyczalni, zatem od 39 (PWr) do 60 (PŚl, 
UP Wr) godzin tygodniowo. W trzech przypadkach zakres czasowy jest krótszy i wynosi ok. 30 godzin (PŁ - 30 godz., SGGW - 31 godz., WSB-NLU - 33 godz.).

\section{Podsumowanie}

Kolekcjonowanie literatury beletrystycznej $\mathrm{w}$ akademickich bibliotekach specjalistycznych nie jest zjawiskiem powszechnym, ale też nie jednostkowym.

Odpowiedzi na pytanie, czy w ogóle kolekcja beletrystyczna w danej bibliotece się znajduje, udzieliło łącznie 38 dyrektorów (w tym 2 bibliotek uczelni niepublicznych), z tym że w większości były to odpowiedzi negatywne (zob. Wykaz 2). Część dyrektorów w ogóle na to podstawowe pytanie nie odpowiedziała, co obliguje do stwierdzenia, że wyniki opracowano na podstawie niekompletnych danych. Ostatecznej analizy dokonano, bazując na danych uzyskanych z czternastu bibliotek specjalistycznych, w których ten typ księgozbioru występuje (zob. Wykaz 1), aczkolwiek komentarze dyrektorów bibliotek, w których aktualnie nie są gromadzone książki beletrystyczne, znacznie wzbogaciły wiedzę o badanym zjawisku.

\section{Wykaz 2. Akademickie biblioteki specjalistyczne, które nie posiadają zbiorów beletrystycznych Uczelnie techniczne:}

1. Politechnika Białostocka

2. Politechnika Częstochowska

3. Politechnika Gdańska

4. Politechnika Koszalińska

5. Politechnika Krakowska

6. Politechnika Poznańska

7. Politechnika Rzeszowska im. Ignacego Łukasiewicza

8. Politechnika Świętokrzyska w Kielcach

9. Zachodniopomorski Uniwersytet Technologiczny w Szczecinie Uczelnie ekonomiczne:

10. Uniwersytet Ekonomiczny w Krakowie

11. Uniwersytet Ekonomiczny w Poznaniu

12. Uniwersytet Ekonomiczny we Wrocławiu

Uczelnie rolnicze/przyrodnicze:

13. Uniwersytet Przyrodniczy w Poznaniu

14. Uniwersytet Rolniczy w Lublinie, 
15. Uniwersytet Rolniczy im. Hugona Kołłątaja w Krakowie

16. Uniwersytet Technologiczno-Przyrodniczy im. Jana i Jędrzeja Śniadeckich w Bydgoszczy

Uczelnie medyczne:

17. Śląski Uniwersytet Medyczny w Katowicach

18. Uniwersytet Medyczny w Białymstoku

19. Uniwersytet Medyczny w Lublinie

20. Uniwersytet Medyczny w Łodzi

21. Uniwersytet Medyczny im. Karola Marcinkowskiego w Poznaniu

22. Uniwersytet Medyczny im. Piastów Śląskich we Wrocławiu

23. Warszawski Uniwersytet Medyczny

Inne:

24. Krakowska Akademia im. Andrzeja Frycza Modrzewskiego

Na podstawie uzyskanych odpowiedzi można sformułować wniosek, że w większości przypadków obserwuje się znaczne zainteresowanie użytkowników beletrystyką. Są to często użytkownicy aktywni, którzy nie tylko książki wypożyczaja, ale też zabiegają o zakup nowości, wskazując na atrakcyjne i wartościowe tytuły. Wydaje się, że kolekcje beletrystyczne przyciągają czytelników do biblioteki, budzą zainteresowanie tych użytkowników, którzy dotychczas skupiali się wyłącznie na literaturze naukowej i dydaktycznej, co w dobie obserwowanego spadku odwiedzin w bibliotekach naukowych ma istotne znaczenie.

Znaczna jest rozpiętość wykorzystania księgozbioru beletrystycznego - od 2,18\% w GUM do 99\% w SGGW. Z tych porównań należy wyłączyć PL i PO, ze względu na krótki okres, jaki minął od zainicjowania księgozbiorów. Na podstawie przeprowadzonej analizy można stwierdzić, iż stopień wykorzystania księgozbioru w dużym stopniu zależy od tego, czy znajduje się on w wolnym dostępie, czy przechowywany jest w magazynach zamkniętych (AM - 2,18\%, GUM - 3,9\%). Odstępstwem od tej zasady jest PUM, gdzie księgozbiór jest w wolnym dostępie, a mimo to jego wykorzystanie jest niewielkie (5,53\%). Przyczyną niewielkiego zainteresowania tą kolekcją nie może być zatem forma dostępu do niej. Z wypowiedzi dyrektora charakteryzującego księgozbiór wynika, że "są to w większości stare czytadła, lektury, poradniki" ${ }^{6}$, więc być może przyczyną niewielkiego zainteresowania księgozbiorem jest niedostatek ciekawych, atrakcyjnych tytułów.

6 Z pisemnej wypowiedzi zastępcy dyrektora Biblioteki Głównej PUM (dokumentacja autorki). 
Dziękuję wszystkim dyrektorom akademickich bibliotek specjalistycznych, którzy wzięli udział w badaniach.

\title{
Bibliografia
}

Koniaszewska T., Uniejewska A., Zysek-Nockowska E., Biblioteka beletrystyczna na Politechnice Wroctawskiej w latach 1953-2007. Historia - zbiory - czytelnictwo, w: VI Wroctawskie Spotkania Bibliotekarzy Polonijnych, red. H. Szarski, M. Kuziela, Wrocław 2008 („Z Problemów Bibliotek Naukowych Wrocławia”), s. 207-230, http://www.dbc.wroc.pl/dlibra/docmetadata?id=2233\&from=publication [dostęp: 3.08.2016].

Kuziela M., Dary kontrolowane - jak wptywać na jakość i ilość darów wprowadzanych do ksiegozbioru, w: Gromadzenie zbiorów - sztuka wyboru, Materiały konferencyjne 11, II Seminarium, Wrocław, 23-24 czerwca 2005 r., Wrocław 2005, http:// www.ebib.pl/publikacje/matkonf/grom2/kuziela.php [dostęp: 2.06.2016].

Marecka E., Biblioteki zakładowe, „Bibliotekarz” 1994, nr 10, s. 11-13.

Wołoch K., Jeszcze w sprawie bibliotek beletrystycznych w zakładach pracy, „Bibliotekarz" 1997, nr 4, s. 14-17.

\section{EWA DOBRZYŃSKA-LANKOSZ}

\section{Collections of fiction books in Polish specialist and research libraries}

\begin{abstract}
Acquisition and circulation of fiction in academic and university libraries is fully justified and requires no explanation as this kind of literature provides valuable source material for study to researchers and students alike. In contrast, specialist technical, medical agricultural, economic and military libraries have no statutory obligation to collect fiction, even though some of them do make this literature available in their collections. The present article discusses the following: provenance of library fiction book collections in academic specialist libraries, interest in fiction shown by their library patrons, methods for circulating fiction and acquisition of new titles and sources of funding.
\end{abstract}

Key words: Polish specialist academic libraries, collections of fiction. 
